\title{
Model of flow resistance coefficient for a fragment of a porous material deposit with anisotropic skeletal structure.
}

\author{
Grzegorz Wałowski ${ }^{a *}$ \\ ${ }^{a}$ Institute of Technology and Life Sciences, Falenty, Al. Hrabska 3, 05-090 Raszyn, Poland \\ Branch Poznan, Department of Renewable Energy Resources, 67 Biskupińska Street , 60-463 \\ Poznan, Poland, \\ e-mail address: walowski.g@gmail.com or g.walowski@itp.edu.pl
}

* Corresponding author

\begin{abstract}
The hydrodynamic results obtained from the permeability of porous materials not only affect the assessment of the stream of the gas flow through those materials but they also refer to the loss of pressure energy in that flow. The direct measure of that loss is flow resistances. The results of experimental research upon the assessment of the flow resistances of porous materials with respect to gas flow. The research conducted applied to natural materials with an anisotropic gap-porous structure. The tests were carried out on a gas permeability measuring system, adapted to different shapes of porous material samples. The process issue of the total pressure drop on a porous deposit was considered in the Reynolds number category. The coefficient of flow resistance for anisotropic materials was defined and the value of this coefficient was compared to the gas stream and the total pressure drop on the porous bed was experimentally evaluated.
\end{abstract}

Keywords: flow resistance, gas, porous material, permeability 


\section{List of major signs}

A

K

$L$

$P$

$Q$

Re

$T$

V

$a$

e

$d$

$f$

$w$

$\Delta P$

$\Psi$

$\varepsilon$

$\eta$

$\lambda$

$\xi$

$\pi$

$\rho$

$\chi$

$\vartheta$ total cross-section of the flow channel

$\mathrm{m}^{2}$

permeability coefficient

$\mathrm{m}^{2}$

flow path length describing the porous bad height

$\mathrm{m}$

pressure gauge

$\mathrm{Pa}$

$\mathrm{m}^{3} / \mathrm{s}$

Reynolds number

thermometer

volume

$\mathrm{m}^{3}$

experimental constant

indicator porosity

diameter

$\mathrm{m}$

function

velocity

$\mathrm{m} / \mathrm{s}$

pressure drop, resistance flow

$\mathrm{Pa}$

tortuosity

porosity

fluid viscosity

$\mathrm{Pa} \cdot \mathrm{s}$

coefficient of linear resistance

coefficient of flow resistance

Pi number

fluid density

$\mathrm{kg} / \mathrm{m}^{3}$

coefficient of tortuosity

density of a solid body
${ }^{0} \mathrm{C}$ $\mathrm{kg} / \mathrm{m}^{3}$ 


\section{Upper indices refer to}

$\begin{array}{ll}* & \text { own model } \\ n & \text { constant }\end{array}$

\section{Lower indices refer to}

$B$

$B-K$

B-K-C

$B-P$

E

$T$

W

Z

$a$

$b$

$c$

e

ef

$g$

$o$

$r$

re

$s$

$z m$

$\varepsilon$

acc. Brauer

acc. Black-Kozeny

acc. Black-Kozeny-Carman

acc. Burke-Plummer

acc. Ergun

acc. Tallmage

acc. Windsperger

acc. Zaworonkow

apparent

absolute

total

equivalent

effective

gas

value calculated on the total deposit section - apparent value

nozzle

reference

skeleton

measured

value calculated relative to the porosity 


\section{Introduction}

Under natural conditions, the flow of fluids in porous structures is connected with the movement of gases and liquids in geological deposits (Dyrka, 2013). These deposits, as primary reservoirs, are areas of migration (Caillet et al., 1997; Carter et al., 2011; Dasgupta et al., 2016; Dixit et al., 2017; Fan et al., 2016; Hill and Nelson, 2000; Lampe et al., 2012; Lee and Williams, 2000; Liu et al., 2016; Osborne and Swarbrick, 1997; Tingay et al., 2009. Wu et al., 2016; Xu et al., 2017; Zeng, 2010) of such substances as crude oil or natural gas, but also of the movement of other liquids and gases, such as water brine or methane in rock masses of hard coal. In each of these cases, the recognition of gas flow conditions through porous deposits can contribute significantly to a better understanding of the mechanisms of gas flow and migration in a given rock bed, which may also be associated with more efficient extraction of gas from natural geological deposits. This is all the more important as the growing industrialization causes the economy to become increasingly interested in additional resources of energy resources.

The hydrodynamic results obtained from the permeability of porous materials not only affect the assessment of the stream of the gas flow through those materials but they also refer to the loss of pressure energy in that flow. The direct measure of that loss is flow resistances that may be interpreted differently in the detailed quantitative assessment. By analysing research studies (Amao, 2007; Bębenek and Bębenek, 1987; Błaszczyk, 2014; Ergun, 1952; Kembłowski et al., 1985; Orzechowski et al., 2009; Piecuch, 2009; Strzelecki et al., 2008) on modelling resistances of the flow through porous deposits it may be noticed that their authors consider the movement criterion - Reynolds number (Amao, 2007; Peszyńska et al., 2010) and interpret hydrodynamic conditions of that flow in a different manner. On the other hand, modifications to the Darcy-Weisbach (Piecuch, 2009; Strzelecki et al., 2008) equation (1) that 
enables calculating the flow resistances most frequently refer to granular structures or porous deposits in the form of the permanent infill of column apparatuses.

$\Delta P=\lambda_{e} \frac{\rho w_{e}^{2}}{2} \frac{L}{d_{e}}$

In which the coefficient of resistance (2):

$\lambda_{e}=f(\mathrm{Re})=a \mathrm{Re}^{n-2}$

Where the Raynolds number (3) equals to:

$$
R e=\frac{w_{e} d_{e} \rho}{\eta}
$$

On the other hand, there is no specific reference of this problem to porous materials with permanent frame structure. Assuming that the coefficient of resistances defined by the equation (4) may be representative for all those cases - as an equivalent measure of flow hydrodynamics.

$\xi=\frac{2}{\rho w^{2}} \Delta P$

The article some of those modifications were compared to the obtained measurement results. This comparison was based on the definitions of the coefficient of resistances set forth Table 1.

\section{Table 1}

Correlation equations for calculation of a coefficient of resistances of the flow through granular porous structures. 


\begin{tabular}{|c|c|c|c|c|}
\hline Autor & Model equation & & Criteria number & \\
\hline $\begin{array}{l}\text { Ergun (Ergun, } \\
\text { 1952) }\end{array}$ & $\xi_{E}=\frac{150}{\operatorname{Re}_{\varepsilon}}+1,75$ & (5) & & \\
\hline $\begin{array}{l}\text { Brauer (Brauer, } \\
\text { 1971) }\end{array}$ & $\xi_{B}=\frac{160}{\operatorname{Re}}+\frac{3,1}{\operatorname{Re}^{0,1}}$ & (6) & & \\
\hline $\begin{array}{l}\text { Tallmage } \\
\text { (Kasieczka, } \\
\text { 2011) }\end{array}$ & $\xi_{T}=\frac{150}{\operatorname{Re}_{\varepsilon}}+\frac{4,2}{\operatorname{Re}_{\varepsilon}^{0,1666}}$ & (7) & $\operatorname{Re}_{\varepsilon}=\frac{w_{o} \cdot d_{\varepsilon} \cdot \rho}{(1-\varepsilon) \cdot \eta}$ & (13) \\
\hline $\begin{array}{l}\text { Burke-Plummer } \\
\text { (Guimard et al., } \\
\text { 2004) }\end{array}$ & $\xi_{B-P}=0,878 \cdot \frac{(1-\varepsilon)}{\varepsilon^{2}}$ & (8) & & \\
\hline $\begin{array}{l}\text { Black-Kozeny } \\
\text { (Guimard et al., } \\
\text { 2004) }\end{array}$ & $\xi_{B-K}=75 \cdot \frac{(1-\varepsilon)^{2}}{\varepsilon^{3}} \cdot \frac{1}{\operatorname{Re}_{\varepsilon}}$ & (9) & $w \cdot d \cdot \rho$ & \\
\hline $\begin{array}{l}\text { Black-Kozeny- } \\
\text { Carman } \\
\text { (Kembłowski et } \\
\text { al., 1985) }\end{array}$ & $\xi_{B-K-C}=\frac{180}{\operatorname{Re}_{\varepsilon}}$ & (10) & $\operatorname{Re}_{\varepsilon}=\frac{o}{\eta}$ & (14) \\
\hline $\begin{array}{l}\text { Żaworonkow } \\
\text { (Zaworonkow, } \\
\text { 1944) }\end{array}$ & $\xi_{Z}=\frac{3,8}{\operatorname{Re}_{\varepsilon}^{0,2}}$ & (11) & $\operatorname{Re}_{\varepsilon}=\frac{w_{o} \cdot d_{\varepsilon} \cdot \rho}{\varepsilon \cdot \eta}$ & (15) \\
\hline $\begin{array}{l}\text { Windsperger } \\
\text { (Windsperger, } \\
\text { 1991) }\end{array}$ & & (12) & $\operatorname{Re}_{\varepsilon}=\frac{2}{3} \cdot \frac{w_{o} \cdot d_{\varepsilon} \cdot \rho}{(1-\varepsilon) \cdot \eta}$ & (16) \\
\hline
\end{tabular}

The values of the coefficient of resistances correspond to the resistance coefficients correlated according to the models detailed in this table at a constant quotient value of linear reference dimensions (17):

$\frac{L}{d_{\varepsilon}}=1$

This is caused by the great complexity of hydrodynamic phenomena for the gas flow through frame-structured porous materials and by a limited number of computational models and methods characteristic for the hydrodynamics of liquid flow in the closed structures.

One of those possibilities is to include in the hydrodynamics description the conditions resulting from the energy dissipation that occurs during the movement of gas in porous and capillar spaces of porous materials. From an experimental view point, this phenomena may be associated with a certain alternative (equivalent) coefficient of resistance that includes 
conditions resulting from the coefficient of friction between liquid and walls of flow channels and from the pressure reduction caused by the disturbance to the velocity profile characteristic for stream choking. In such presented issue, the total resistance of gas flow through the porous deposit may be identified with the general dependency (18), considering the relevant adjustment of flow parameters of the porous structure:

$$
\Delta P=\xi \frac{\rho w^{2}}{2}
$$

This approach is justified by the fact that in the structure of flow micro-channels a share of friction in the flow resistance is marginal.

When directly using the Weisbach (Strzelecki et al., 2008) equation (18) it needs to be directly adapted to the porous structure, for which this equation may be as follows (19):

$$
\Delta P=\xi_{\varepsilon} \frac{\rho_{g} w_{\varepsilon}^{2}}{2}
$$

In this case, the flow velocity $w_{\varepsilon}(20)$ refers to the section resulting from the average area of the deposit $A_{\varepsilon}$ open for this flow and resulting from the porosity of the deposit $\varepsilon$ and its complete section $A_{\boldsymbol{o}}$. Hence

$$
w_{\varepsilon}=\frac{Q_{g}}{A_{\varepsilon}}=\frac{Q_{g}}{\varepsilon A_{o}}
$$

For such interpreted conditions the equation (19) may be used to experimentally determine a value of the coefficient of flow resistance as its value $\xi_{\varepsilon},(21)$ that cumulatively consider all the mechanisms resulting from the hydrodynamics of the gas flow through porous materials: 


$$
\xi_{\varepsilon}=\frac{2}{\rho_{g} w_{\varepsilon}^{2}} \Delta P_{z m}
$$

\section{Materials and method}

The permeability research was conducted upon materials, the average porosity of which ranged $40.3 \%$. Chars in situ are direct products of underground coal gasification and they were acquired from the experimental georeactor (semi-technical scale) of the "Barbara" Experimental Mine (Wiatowski et al., 2012; Stańczyk et al., 2012). In this case, the process conditions enhanced the almost complete gasification of coal but the structure of this product is also extremely diversified, which - apart from process conditions - depends on the place where the sample is acquired from.

The parameters determined for the tested materials - samples are outlined in Table 2 together with sample numbers and average values of those parameters.

\section{Table 2}

Characteristic of research material.

\begin{tabular}{|c|c|c|c|c|c|c|}
\hline \multirow{2}{*}{\multicolumn{2}{|c|}{$\begin{array}{c}\text { Material } \\
\text { (designation and source } \\
\text { origin of raw material) }\end{array}$}} & \multicolumn{2}{|c|}{ Porosity } & \multirow{3}{*}{$\begin{array}{c}\text { Indicator } \\
\text { porosity } \\
\text { e }\end{array}$} & \multicolumn{2}{|c|}{$\begin{array}{c}\text { Density } \\
\text { of a solid body }\end{array}$} \\
\hline & & absolute & effective & & \multirow{2}{*}{$\begin{array}{c}\text { apparent } \\
\vartheta_{\mathrm{a}} \\
\mathrm{kg} / \mathrm{m}^{3} \\
\end{array}$} & \multirow{2}{*}{$\begin{array}{c}\text { skeleton } \\
\vartheta_{\mathrm{s}}, \\
\mathrm{kg} / \mathrm{m}^{3}\end{array}$} \\
\hline name & no. sample & $\%$ & $\%$ & & & \\
\hline 1 & 2 & 3 & 4 & 5 & 6 & 7 \\
\hline \multirow{4}{*}{$\begin{array}{c}\text { char (carbonizer) } \\
\text { in situ } \\
\text { (KD Barbara, } \\
\text { Mikolow) }\end{array}$} & $\mathrm{I}-1$ & 42.2 & $21.1 \div 33.7$ & 0.7 & 1300 & \\
\hline & $\mathrm{I}-2$ & 44.9 & $22.5 \div 35.9$ & 0.8 & 1239 & 2250 \\
\hline & I-3 & 33.9 & $17.0 \div 27.1$ & 0.5 & 1487 & \\
\hline & I - average & 40.3 & $20.2 \div 32.2$ & 0.7 & 1342 & 2250 \\
\hline
\end{tabular}

The porous material also underwent physical assessment of their structure. This assessment was conducted on the basis of available SEM images (Wałowski, 2015). These observations confirm that the graphical identification of the structure of porous materials is a 
source of much more information that is suitable to assess the permeability of these materials when compared to their porosity degree.

\subsection{Experimental stand}

Test applied to gas permeability measurement system as shown in Fig. 1, adjusted to the different shapes of the porous material samples.

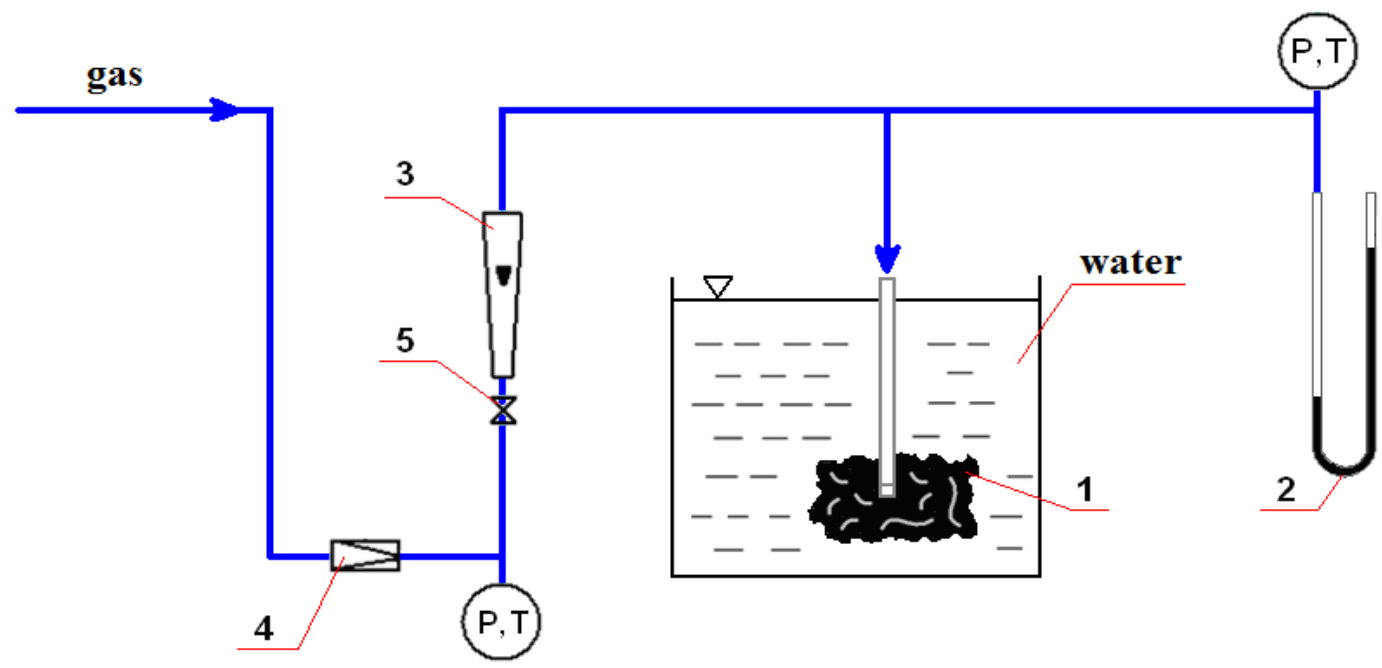

Fig. 1. Scheme of measurement system for porous material permeability tests in barbotage conditions: 1 - porous material (sample), 2 - differential pressure manometer, 3 - rotameter (3a- bubble flowmeter), 4 - pressure reductors, 5 - control valve, $\mathrm{P}$ - pressure gauge, $\mathrm{T}$-thermometer.

The measurement system Fig. 1 is designed for determining the permeability of materials in barbotage conditions. This measurement method is applied for samples with undefined shapes (volume ones) that resulted from naturally obtained parts of the samples. This enabled the assessment of the permeability intensity and the direction of the gas stream with respect to the sample surface.

The working media applied in the gas permeability tests were air. In each case, gas flowed through sample (1) in the free-pressure regime, the reference pressure in the pressure reducing valve (4) was $(0.1 \div 0.4) \mathrm{MPa}$ and gas freely flowed out. Air was taken from the compressed air system at the reference temperature of $21.7^{\circ} \mathrm{C}$. The decline in pressure in the specific 
measurement system was measured with differential pressure manometers (2) installed in the stream measurement system at the gas inlet to the material sample. The gas stream was measured with flota-controlled rotameters (3) scaled with the bellows gas meter before conducting the tests. By using valves (5) to adjust the gas stream, permeability characteristics of the tested samples were determined for system. All the results of the gas stream measurements were referred to as normal conditions $(293 \mathrm{~K}, 1013 \mathrm{hPa})$.

The shape of this type of sample together with a visible supply connection pipe (nozzle) is illustrated in Fig. 2 - the images refer to the volume sample of char in situ (indefinite shape).

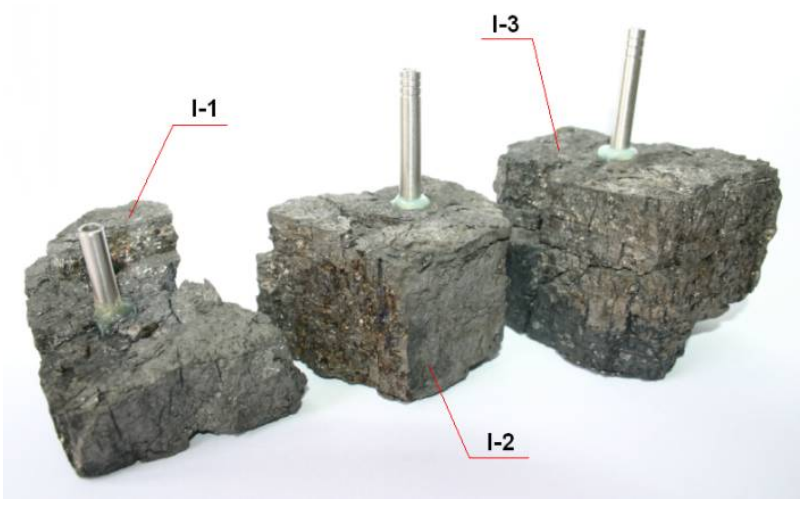

Fig. 2. Samples of porous material of different shapes - char in situ: I-1, I-2, I-3.

Fig. 3 shows the applied sample supply system for the free gas flow (with the marking of the agreed parameters) and illustrates the gas conduct in these conditions.

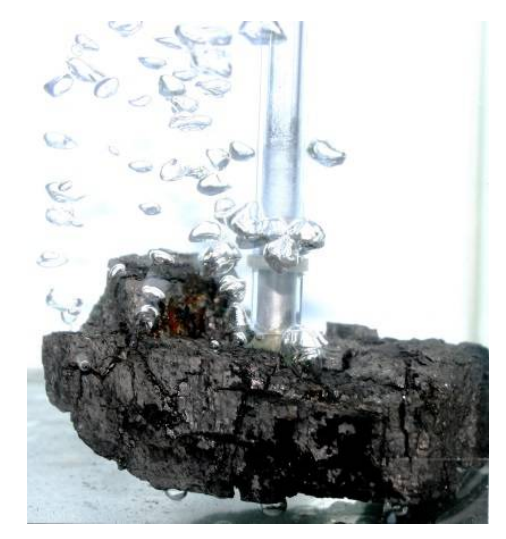

Fig. 3. Gas flow in barbotage conditions - char in situ: I-1.

To obtain the research objective, detailed experimental tests were conducted to assess the gas permeability of porous materials structure and the tests results are presented in Table 3. 


\section{Table 3}

Test results in conditions: air, $21.7^{0} \mathrm{C}$

\begin{tabular}{|c|c|c|c|c|c|c|c|}
\hline \multicolumn{8}{|c|}{$\begin{array}{l}\text { Research material: Char in situ } \\
\text { No. sample: I-1 }\end{array}$} \\
\hline No. & $\begin{array}{l}\text { Reference } \\
\text { pressure } \\
\mathrm{P}_{\text {re }}, \mathrm{MPa}\end{array}$ & $\begin{array}{l}\text { Gas stream } \\
\mathrm{Qg}_{\mathrm{g}} \cdot 10^{3}, \mathrm{~m}^{3} / \mathrm{s}\end{array}$ & $\begin{array}{l}\text { Resistance } \\
\text { flow } \\
\text { measured } \\
\Delta \mathrm{P}_{\mathrm{zm}}, \mathrm{kPa}\end{array}$ & No. & $\begin{array}{l}\text { Reference } \\
\text { pressure } \\
\text { Pre, MPa }\end{array}$ & $\begin{array}{l}\text { Gas stream } \\
\mathrm{Qg}_{\mathrm{g}} \cdot 10^{3}, \mathrm{~m}^{3} / \mathrm{s}\end{array}$ & $\begin{array}{l}\text { Resistance } \\
\text { flow } \\
\text { measured } \\
\Delta \mathrm{P}_{\mathrm{zm}}, \mathrm{kPa}\end{array}$ \\
\hline 1 & 0,1 & 0,161 & 10,2 & 26 & 0,3 & 0,161 & 9,7 \\
\hline 2 & 0,1 & 0,182 & 11,3 & 27 & 0,3 & 0,182 & 11,3 \\
\hline 3 & 0,1 & 0,196 & 12,9 & 28 & 0,3 & 0,217 & 16,6 \\
\hline 4 & 0,1 & 0,203 & 13,8 & 29 & 0,3 & 0,238 & 20,4 \\
\hline 5 & 0,1 & 0,217 & 16,6 & 30 & 0,3 & 0,259 & 23,9 \\
\hline 6 & 0,1 & 0,231 & 17,9 & 31 & 0,3 & 0,287 & 29,3 \\
\hline 7 & 0,1 & 0,238 & 20,6 & 32 & 0,3 & 0,315 & 33,5 \\
\hline 8 & 0,1 & 0,266 & 23,9 & 33 & 0,3 & 0,350 & 44,1 \\
\hline 9 & 0,1 & 0,280 & 27,2 & 34 & 0,3 & 0,371 & 51,2 \\
\hline 10 & 0,1 & 0,301 & 29,9 & 35 & 0,3 & - & - \\
\hline 11 & 0,1 & 0,329 & 37,9 & 36 & 0,3 & - & - \\
\hline 12 & 0,1 & 0,350 & 42,8 & 37 & 0,3 & - & - \\
\hline 13 & 0,1 & 0,371 & 49,2 & 38 & 0,3 & - & - \\
\hline 14 & 0,2 & 0,161 & 9,9 & 39 & 0,4 & 0,161 & 10,6 \\
\hline 15 & 0,2 & 0,189 & 12,6 & 40 & 0,4 & 0,196 & 12,7 \\
\hline 16 & 0,2 & 0,210 & 15,2 & 41 & 0,4 & 0,231 & 19,2 \\
\hline 17 & 0,2 & 0,231 & 19,2 & 42 & 0,4 & 0,266 & 24,2 \\
\hline 18 & 0,2 & 0,252 & 23,2 & 43 & 0,4 & 0,301 & 31,2 \\
\hline 19 & 0,2 & 0,280 & 26,9 & 44 & 0,4 & 0,336 & 39,9 \\
\hline 20 & 0,2 & 0,301 & 31,2 & 45 & 0,4 & 0,350 & 43,6 \\
\hline 21 & 0,2 & 0,322 & 36,1 & 46 & 0,4 & 0,371 & 51,2 \\
\hline 22 & 0,2 & 0,336 & 38,9 & 47 & 0,4 & - & - \\
\hline 23 & 0,2 & 0,343 & 42,8 & 48 & 0,4 & - & - \\
\hline 24 & 0,2 & 0,371 & 49,4 & 49 & 0,4 & - & - \\
\hline 25 & 0,2 & 0,392 & 53,4 & 50 & 0,4 & - & - \\
\hline
\end{tabular}

\begin{tabular}{|c|c|c|c|c|c|c|c|}
\hline \multicolumn{8}{|c|}{$\begin{array}{l}\text { Research material: Char in situ } \\
\text { No. sample: I-2 }\end{array}$} \\
\hline No. & $\begin{array}{l}\text { Reference } \\
\text { pressure } \\
\text { Pre, } \mathrm{MPa}\end{array}$ & $\begin{array}{l}\text { Gas stream } \\
\mathrm{Qg}_{\mathrm{g}} \cdot 10^{3}, \mathrm{~m}^{3} / \mathrm{s}\end{array}$ & $\begin{array}{l}\text { Resistance } \\
\text { flow } \\
\text { measured } \\
\Delta \mathrm{P}_{\mathrm{zm}}, \mathrm{kPa}\end{array}$ & No. & $\begin{array}{l}\text { Reference } \\
\text { pressure } \\
\text { Pre }_{\text {re }} \mathrm{MPa}\end{array}$ & $\begin{array}{l}\text { Gas stream } \\
\mathrm{Qg}_{\mathrm{g}} \cdot 10^{3}, \mathrm{~m}^{3} / \mathrm{s}\end{array}$ & $\begin{array}{l}\text { Resistance } \\
\text { flow } \\
\text { measured } \\
\Delta \mathrm{P}_{\mathrm{zm}}, \mathrm{kPa}\end{array}$ \\
\hline 1 & 0,1 & 0,161 & 7,4 & 24 & 0,3 & 0,378 & 28,1 \\
\hline 2 & 0,1 & 0,182 & 7,3 & 25 & 0,3 & 0,427 & 30,3 \\
\hline 3 & 0,1 & 0,196 & 8,5 & 26 & 0,3 & 0,539 & 46,6 \\
\hline 4 & 0,1 & 0,231 & 11,3 & 27 & 0,3 & 0,553 & 49,2 \\
\hline 5 & 0,1 & 0,252 & 12,2 & 28 & 0,3 & 0,637 & 66,6 \\
\hline 6 & 0,1 & 0,266 & 13,9 & 29 & 0,3 & 0,686 & 85,3 \\
\hline 7 & 0,1 & 0,301 & 15,9 & 30 & 0,3 & - & - \\
\hline 8 & 0,1 & 0,322 & 17,9 & 31 & 0,3 & - & - \\
\hline 9 & 0,1 & 0,357 & 20,3 & 32 & 0,3 & - & - \\
\hline 10 & 0,1 & 0,385 & 24,4 & 33 & 0,3 & - & - \\
\hline 11 & 0,1 & 0,427 & 31,6 & 34 & 0,3 & - & - \\
\hline 12 & 0,2 & 0,161 & 6,9 & 35 & 0,4 & 0,532 & 45,4 \\
\hline 13 & 0,2 & 0,196 & 8,2 & 36 & 0,4 & 0,637 & 67,8 \\
\hline 14 & 0,2 & 0,231 & 9,9 & 37 & 0,4 & 0,651 & 73,2 \\
\hline 15 & 0,2 & 0,252 & 12,2 & 38 & 0,4 & 0,728 & 99,1 \\
\hline 16 & 0,2 & 0,280 & 13,9 & 39 & 0,4 & 0,763 & 114,5 \\
\hline 17 & 0,2 & 0,308 & 16,2 & 40 & 0,4 & - & - \\
\hline 18 & 0,2 & 0,336 & 19,2 & 41 & 0,4 & - & - \\
\hline 19 & 0,2 & 0,357 & 20,8 & 42 & 0,4 & - & - \\
\hline 20 & 0,2 & 0,385 & 24,6 & 43 & 0,4 & - & - \\
\hline 21 & 0,2 & 0,413 & 28,5 & 44 & 0,4 & - & - \\
\hline 22 & 0,2 & 0,490 & 39,9 & 45 & 0,4 & - & - \\
\hline 23 & 0,2 & 0,553 & 49,3 & 46 & 0,4 & - & - \\
\hline
\end{tabular}




\begin{tabular}{|c|c|c|c|c|c|c|c|}
\hline \multicolumn{8}{|c|}{$\begin{array}{l}\text { Research material: Char in situ } \\
\text { No. sample: I-3 }\end{array}$} \\
\hline No. & $\begin{array}{l}\text { Reference } \\
\text { pressure } \\
\mathrm{P}_{\text {re }}, \mathrm{MPa}\end{array}$ & $\begin{array}{l}\text { Gas stream } \\
\mathrm{Qg}_{\mathrm{g}} \cdot 10^{3}, \mathrm{~m}^{3} / \mathrm{s}\end{array}$ & $\begin{array}{l}\text { Resistance } \\
\text { flow } \\
\text { measured } \\
\Delta \mathrm{P}_{\mathrm{zm}}, \mathrm{kPa}\end{array}$ & No. & $\begin{array}{l}\text { Reference } \\
\text { pressure } \\
\mathrm{P}_{\text {re }}, \mathrm{MPa}\end{array}$ & $\begin{array}{l}\text { Gas stream } \\
\mathrm{Qg}_{\mathrm{g}} \cdot 10^{3}, \mathrm{~m}^{3} / \mathrm{s}\end{array}$ & $\begin{array}{l}\text { Resistance } \\
\text { flow } \\
\text { measured } \\
\Delta \mathrm{P}_{\mathrm{zm}}, \mathrm{kPa}\end{array}$ \\
\hline 1 & 0,1 & 0,161 & 8,9 & 13 & 0,3 & 0,308 & 30,8 \\
\hline 2 & 0,1 & 0,196 & 12,6 & 14 & 0,3 & 0,434 & 65,4 \\
\hline 3 & 0,1 & 0,231 & 17,5 & 15 & 0,3 & 0,490 & 86,9 \\
\hline 4 & 0,1 & 0,266 & 21,5 & 16 & 0,3 & 0,546 & 108,6 \\
\hline 5 & 0,1 & 0,301 & 27,6 & 17 & 0,3 & 0,588 & 128,1 \\
\hline 6 & 0,2 & 0,161 & 9,7 & 18 & 0,4 & 0,371 & 48,1 \\
\hline 7 & 0,2 & 0,196 & 13,4 & 19 & 0,4 & 0,525 & 99,1 \\
\hline 8 & 0,2 & 0,238 & 18,3 & 20 & 0,4 & 0,581 & 126,3 \\
\hline 9 & 0,2 & 0,343 & 38,7 & 21 & 0,4 & 0,623 & 140,9 \\
\hline 10 & 0,2 & 0,385 & 50,9 & 22 & 0,4 & - & - \\
\hline 11 & 0,2 & 0,434 & 64,5 & 23 & 0,4 & - & - \\
\hline 12 & 0,2 & 0,476 & 77,6 & 24 & 0,4 & - & - \\
\hline
\end{tabular}

\subsection{Scope and research methodology}

To assess the hydrodynamics of gas flow through porous materials, tests were carried out with respect to volume samples with undefined shapes - Fig. 4.

a)

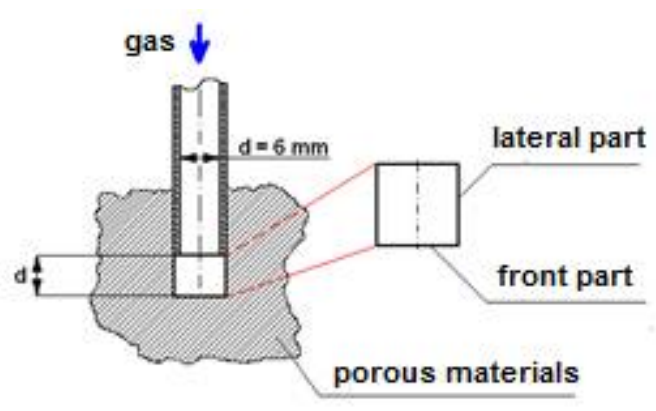

b)

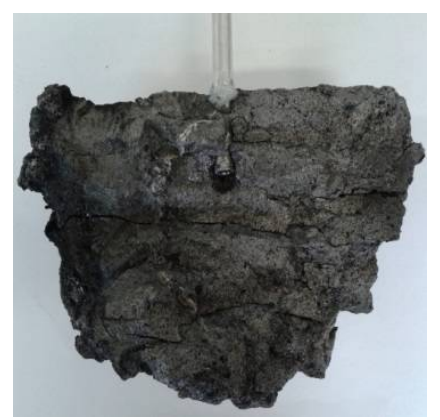

Fig. 4. Supply system of volume sample (a) and its cross-sectional view (b).

The test were conducted with reference to gas - air, with regard to the permeability stream resulting from the reference pressure. Moreover, the permeability function of the pressure decline in the porous deposit was independently determined, assuming the so-called multioriented fractal, system for gas flow through samples Fig. 5. 


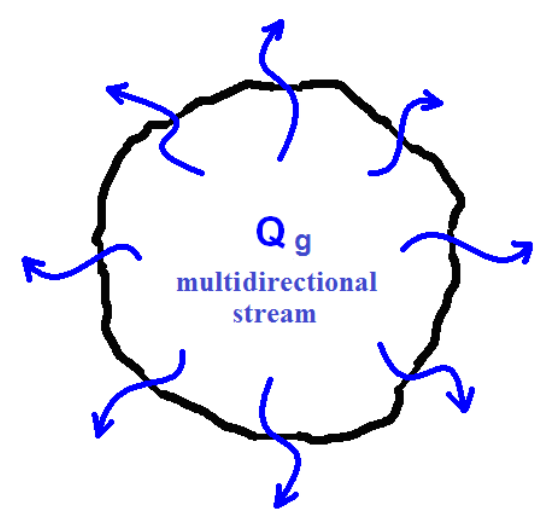

Fig. 5. Scheme of flow system: multi-oriented - fractal, volume sample, where: $Q_{g}$ - stream gas.

\section{Results and discussion}

The results for the determined flow resistance coefficient (21) for volumetric samples are given in Fig. 6. There was used the reference of the value of this coefficient to the Reynolds number (22) at a gas speed of $w_{o}$ resulting from the $d$ diameter of the feeding nozzle - Fig. 4.

$R e=\frac{w_{o} d \rho_{g}}{\eta_{g}}$ 


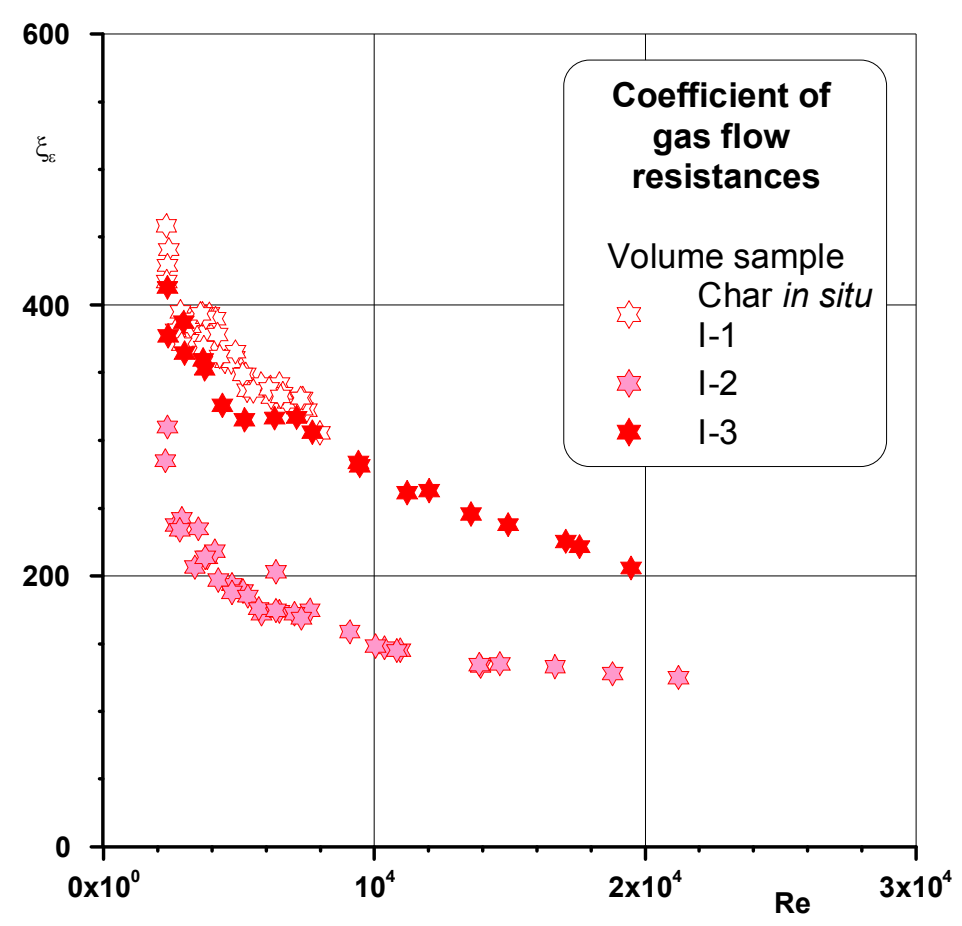

Fig. 6. Coefficient of gas flow resistances for volume sample - char in situ: I-1, I-2, I-3.

Those results show a decrease in changes to the value of the resistance coefficient as a result of an increase in the Reynolds number, which complies with the physics of the analysed phenomena but the scale of those changes is sometimes extensive. This proves that the flow resistances are highly affected by the dynamics of gas flow through porous materials, in particular by disturbances of the velocity profile. This tendency and the measuring range simultaneously indicate that for coal char in situ - Fig. 6 - a turbulent nature of the gas movement is noted, which is proven by the non-linear nature of this coefficient. It may be noted that coal char in situ has the minimum flow resistance - Fig. 6. Undoubtedly, this results from the fact that this material - despite its small porosity - has a very extensive system of pores and open channels for the gas flow.

The change to the value of the coefficient of resistances with respect to the Reynolds number proves - Fig. 6, that when modelling hydrodynamic conditions of the gas flow through solid porous materials it is necessary to consider the relation (23): 


$$
\xi_{\varepsilon}=f(\operatorname{Re}, \varepsilon)
$$

This also refers to the Reynolds number which, in this case, may take a different form - Table 1. In the reference books, there is still a debate (Peszyńska and Trykozko, 2013) on how to best describe this criteria number to identify the flow through frame-structured porous materials. As for those materials it is very difficult or even impossible to assess diameters of pores and capillars, and their actual flow speed, Bear and Cheng (Bear and Cheng, 2010) suggest that in this case the Reynolds number (24) should be defined with respect to the entire volume of the porous material referred to the flow section:

$R e_{\varepsilon}=\frac{w_{\varepsilon} d_{\varepsilon}^{*} \rho_{g}}{\eta_{g}}$

The characteristic linear measurement is calculated as an alternative diameter resulting from the volume of the porous material and the section active for the flow, viz. (25):

$$
d_{\varepsilon}^{*}=\frac{V_{c}}{\varepsilon A_{o}}
$$

On the other hand, velocity is a result of the deposit porosity and is associated with an apparent velocity (calculated for the entire cross-section of the deposit (26):

$$
w_{\varepsilon}=\varepsilon w_{o}
$$

The conducted analyses show that the method resulting from the equations (24-26) and determining the criteria Reynolds number does not reflect in the best way any hydrodynamic conditions subject to the gas low through frame-structured porous materials. This is due to the fact that the subject of the research was the samples with different shapes. Especially in case 
of the volume solid the determination of the cross-section for the flow direction is very difficult and imprecise. To meet those problems, an attempt was made to develop an alternative model based on the change to the kinetic energy characteristic for all resistances to the gas flow through the porous medium.

According to (21) this may be as follows (27):

$$
\xi_{\varepsilon}(\mathrm{Re})=\frac{2 \Delta P_{c}}{\rho_{g} w_{\varepsilon}^{2}}
$$

Considering the diversified shape of the material and its characteristic structural features resulting from its porosity and permeability, the equation (26) may be modified by implementing a correction coefficient in the form of the so-called tortuosity parameter (28):

$\Psi_{\varepsilon}=f\left(K^{*}, \varepsilon\right)$

While the hydrodynamic parameters are known (stream, pressure drop on the bed, and bed porosity and gas type), the value of the gas-permeability coefficient (29) can be determined experimentally and is defined:

$$
K^{*}=\frac{Q_{g}}{\sqrt{\frac{\Delta P_{\mathrm{Z} m}}{\rho_{g}}}}
$$

Them the equation for the total coefficient of resistance is as follows (30):

$$
\xi_{c}(R e)=\frac{2 \Delta P_{c}}{\rho_{g} w_{e}^{2}} \Psi_{\varepsilon}
$$

With respect to such equation the compensatory calculation was conducted for samples in the form of a differently shaped solid (volume one). The arithmetical analysis shows that for the 
volume solid the tortuosity parameter needs to be calculated on the basis of the following dependency (31):

$$
\Psi_{\varepsilon}=\frac{\chi_{\varepsilon}^{a}}{\operatorname{Re}_{\varepsilon}}
$$

The auxiliary function for the exponent $\mathrm{a}=1.5$ (in situ charset) at the base of power is the coefficient of bed formation (32) related to the gas-permeability coefficient and porosity:

$\chi_{\varepsilon}=K^{*(\varepsilon-1)}$

While the Reynolds number (33) takes into account the defined apparent velocity (34):

$R e_{\varepsilon}=\frac{w_{\varepsilon}^{*} d_{r} \rho_{g}}{\eta_{g}}$

The apparent velocity (34) is referred to the entire space of the volume sample feeding as the cross-section resulting from the frontal and lateral area of the feeding nozzle Fig. 4.

$$
w_{\varepsilon}^{*}=\frac{Q_{g}}{A_{o}^{*}}
$$

Cross-sectional area of nozzle feeding the porous material (35):

$$
A_{o}^{*}=\varepsilon_{b}\left(\frac{\pi d_{r}^{2}}{4}+\pi d_{r}^{2}\right)
$$

The obtained results of the function of the coefficient of resistances in the function of the Reynolds number are shown in Fig. 7, which, just to illustrate, also include points resulting from other calculation models (Brauer, 1971; Ergun, 1952; Guimard et al., 2004; Kasieczka, 
2011; Kembłowski et al., 1985; Windsperger, 1991; Zaworonkow, 1944) adjusted by the parameters resulting from the own research. The distribution of experimental points proves that expect for the Zaworonkow (Zaworonkow, 1944) model and the Blake-Kozeny (Guimard et al., 2004) model all the remaining ones show the same trend of changes to this coefficient, which confirms the adequacy of the adopted assumptions.

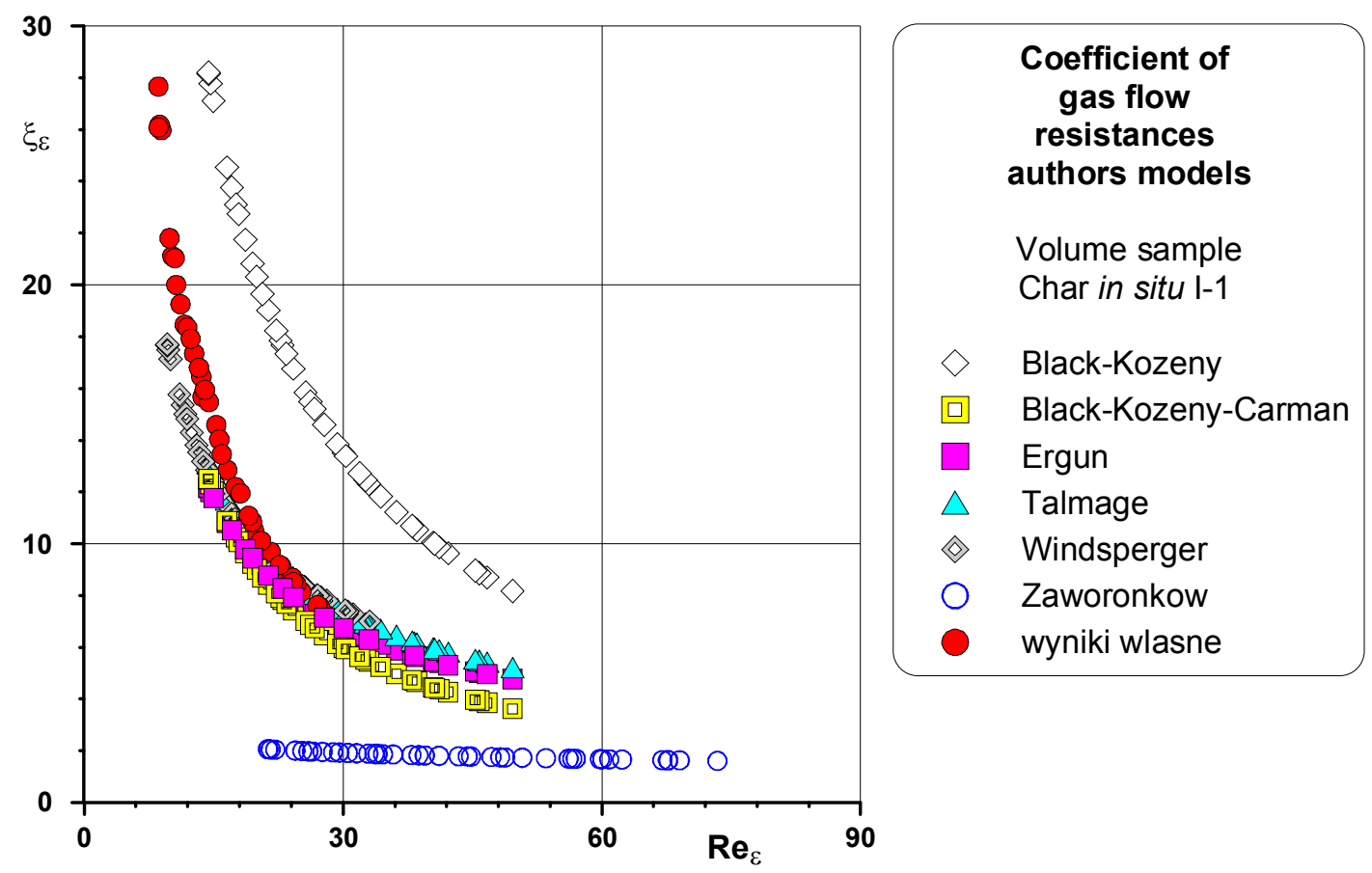

Fig. 7. Coefficient of resistances of gas flow through coal char acc. authors models.

\section{Conclusions}

The conducted experimental research results in the following conclusions:

1) The quantitative assessment of hydrodynamic parameters conducted with respect to booksbased models, particularly in the aspect of flow resistances, has shown that none of the booksbased models correctly correlate with the obtained research results. This is explained by great anisotropic properties of the tested materials and the restricted application of those models with respect to granular not frame-structured materials. 
2) The own calculation model developed on the basis of the acquired results basically describing the coefficient of flow resistances shows a good consistence of the research results with the calculation results;

The research results on hydrodynamics of gas flow through frame-based porous deposits, and the proved usefulness of the process assessment of that research may, in many cases, be practically used.

\section{References}

Amao, A.M., 2007. Mathematical model for Darcy Forchheimer flow with applications to well performance analysis. Master's Thesis, Department of Petroleum Engineering, Texas Tech University, Misato.

Bear, J., Cheng, A., 2010. Modeling groundwater flow and contaminant transport. Springer.

Bębenek, B., Bębenek, H., 1987. Straty energii w przepływach płynów [Energy losses in fluid flows]. Wydawnictwo Politechniki Krakowskiej, Kraków.

Błaszczyk, M., 2014. Badanie procesów migracji substancji ropopochodnych i ich emulsji $w$ strukturach porowatych: praca dokotorska [Research upon processes of migration of petroleum substances and their emulsions in porous structures: doctoral thesis]. Łódź: Politechnika Łódzka, Wydział Chemiczny.

Brauer, H., 1971. Grundlagen der Einphasen - und Mehrphasenströmungen. Frankfurt am Main: Verlag Säuerländer.

Caillet, G., Judge, N. C., Bramwell, N.P., Meclani, L., Green, M., Ada, P., 1997. Overpressure and hydrocarbon trapping in the Chalk of the Norwegian Central Graben. Petroleum Geoscience, 3, 33-42. 
Carter, K.M., Harper, J.A., Schmid, K.W., Kostelnik, J., 2011. Unconventional natural gas resources in Pennsylvania: The backstory of the modern Marcellus Shale play. Environmental Geosciences, 18(4):217-257, DOI:10.1306/eg.09281111008

Dasgupta, S., Chayyerjee, R., Mohanty, S.P., 2016. Magnitude, mechanisms and prediction of abnormal pore pressure using well data in the Krishna Godavari Basin, East coast of India. AAPG Bulletin, 100(12):1833-1855.

Dixit, N.C., Hanks, C.L., Wallace, W.K., Ahmadi, M., Awoleke, O., 2017. In Situ Stress Variations Associated with Regional Changes in Tectonic Setting, northeastern Brooks Range and eastern North Slope of Alaska. AAPG Bulletin, 48 (17) :10107-10115.

Dyrka, I., 2013. Cechy petrofizyczne skał łupkowych. Państwowa służba geologiczna o gazie w tupkach. Środowisko występowania tupków gazonośnych [Petrophysical features of shale rocks. The national geological survey on shale gas. The environment of occurrence of gas-bearing shales]. Państwowy Instytut Geologiczny - Państwowy Instytut Badawczy, Warszawa, 3, 44-47

Ergun, S., 1952. Fluid flow through packed columns. Chemical Engineering Progress, 48(2), 89-94.

Fan, C.Y., Wang, Z.L., Wang, A.G., Fu, S.T., Wang, L.Q., Zhang, Y.S., Kong, H.X., Zhang, X., 2016. Identification and calculation of transfer overpressure in the northern Qaidam Basin, northwest China. AAPG Bulletin, 100(1):23-39.

Guimard, P., McNerny, D., Saw, E., Yang, A., 2004. Pressure drop for flow through packed beds. Team 4, 06-363 Transport Process Laboratory, Carnegie Mellon University, 18 March, 1-14.

Hill, D.G., Nelson, C.R., 2000. Gas Productive Fractured Shales: An Overview and Update, Gas Tips, Gas Research Institute, 6(2):4-18. 
Kasieczka, W., 2011. Badanie hydrodynamiki złoża fluidalnego. Laboratorium. Kotly $i$ wytwornice pary. Ćwiczenie $n r$ K-07 [Investigation of hydrodynamics of a fluidized bed. Lab. Boilers and steam generators. Exercise No. K-07]. Katedra Techniki Cieplnej i Chłodnictwa, Politechnika Łódzka, Łódz, 1-18

Kembłowski, Z., Michałowski, S., Strumiłł, C., Zarzycki, R., 1985. Podstawy teoretyczne inżynierii chemicznej $i$ procesowej [Theoretical foundations of chemical and process engineering]. WN-T, Warszawa.

Lampe, C., Song, G.Q., Cong, L.Z., Mu, X., 2012. Fault control on hydrocarbon migration and accumulation in the Tertiary Dongying depression, Bohai Basin, China. AAPG Bulletin, $96(6)$ :983-1000.

Lee M.K., Williams, D.D., 2000. Paleohydrology of the Delaware Basin, Western Texas: Overpressure Development, Hydrocarbon Migration, and Ore Genesis. AAPG Bulletin, $84(7): 171-180$.

Liu, Y.F., Qiu, N.S., Xie, Z.Y., Yao, Q.Y., Zhu, C.Q., 2016. Overpressure compartments in the Central Paleo-Uplift, Sichuan Basin, southwest China. Journal of Natural Gas Science and Engineering. 100(5):867-888.

Orzechowski Z., Prywer J., Zarzycki R., 2009. Mechanika płynów w inżynierii i ochronie środowiska [Fluid mechanics in engineering and environmental protection]. Wydawnictwo Naukowo-Techniczne, Warszawa.

Osborne, M.J., Swarbrick, R.E., 1997. Mechanisms for generating overpressure in sedimentary basins: A reevaluation. AAPG Bulletin, 81, 1023-1041.

Peszyńska, M., Trykozko, A., 2013. Pore-to-Core simulations of flow with large velocities using continuum models and imaging data. Computational Geosciences, 17(4):623-645. DOI:10.1007/s10596-013-9344-4 
Peszyńska, M., Trykozko, A, Sobieski, W., 2010. Forchheimer law in the computational and experimental of flow through porous media at porescale and mesoscale. GAKUTO International Series. Mathematical Sciences and Applications, 32, 463-482.

Piecuch T., 2009. Równanie Darcy jako podstawa analizy teoretycznej szczególnych przypadków procesu filtracji [Darcy equation as the basis for theoretical analysis of specific cases of the filtration process.]. Rocznik Ochrona Środowiska, 11.

Stańczyk, K., Kapusta, K., Wiatowski, M., Świądrowski, J., Smoliński, A., Rogut, J., Kotyrba, A., 2012. Experimental simulation of hard coal underground gasification for hydrogen production. Fuel, 91, 40-50.

Strzelecki, T., Kostecki, S., Żak, S., 2008. Modelowanie przepływów przez ośrodki porowate [Flow modeling through porous media]. Wrocław: Dolnośląskie Wydawnictwo Edukacyjne.

Tingay, M.R.P., Hillis, R.R., Swarbrick, R.E., Morley, C.K., Damit, A.R., 2009. Origin of overpressure and pore-pressure prediction in the Baram province, Brunei. AAPG Bulletin, 93 (1) :51-74.

Wałowski, G., 2015. Hydrodynamika przepływu gazu przez złoże porowate: praca doktorska [Hydrodynamics of gas flow through porous deposits: doctoral thesis]. Opole: Politechnika Opolska.

Wiatowski, M., Stańczyk, K., Świądrowski, J., Kapusta, K., Cybulski, K., Krause, E., Grabowski, J., Rogut, J., Howaniec, N., Smoliński, A., 2012. Semi-technical underground coal gasification (UCG) using the shaft method in Experimental Mine “Barbara”. Fuel, 99, 170-179.

Windsperger, A., 1991. Abschätzung von spezifischer Oberfläche und Lückengrad bei biologischen Abluftreinigungsanlagen durch Vergleich von berechneten und experimentell erhaltenen Druckverlustwerten. Chemie Ingenieur Technik, 63(1), 80-81. 
Wu, J., Liu, S.G., Wang, G.Z., Zhao, Y.H., Sun, W., Song, J.M., Tan, Y.Y., 2016. MultiStage Hydrocarbon Accumulation and Formation Pressure Evolution in Sinian Dengying FormationCambrian Longwangmiao Formation, Gaoshiti-Moxi Structure, Sichuan Basin. Journal of Earth Science, 27(5):835-845.

Xu, Q., Shi, W., Xie, Y., Wang, Z., Li, X., Tong, C., 2017. Identification of low-overpressure intervaland its implication to hydrocarbon migration: Casestudy in the Yanan sag of the Qiongdongnan Basin,South China Sea. PLoS ONE 12(9): e0183676.https://doi.org/10.1371/journal.pone.0183676Editor.

Zaworonkow, M.N., 1944. Gidrawliczeskije osnowy skrubbernogo processa i tiepłopieredacza w skrubberach. Mscow: Izd. Sow. Nauka.

Zeng, L., 2010. Microfracturing in the Upper Triassic Sichuan Basin Tight-gas Sandstones: Tectonic, Overpressure, and Diagenetic origins. AAPG Bulletin, 94(12):1811-1825.

\section{Acknowledgements}

The study was conducted as part of the project financed by the National Centre for Research and Development conducted in the BIOSTRATEG program, contract No BIOSTRATEG1/269056/5/NCBR/2015 dated 11 August 2015. 